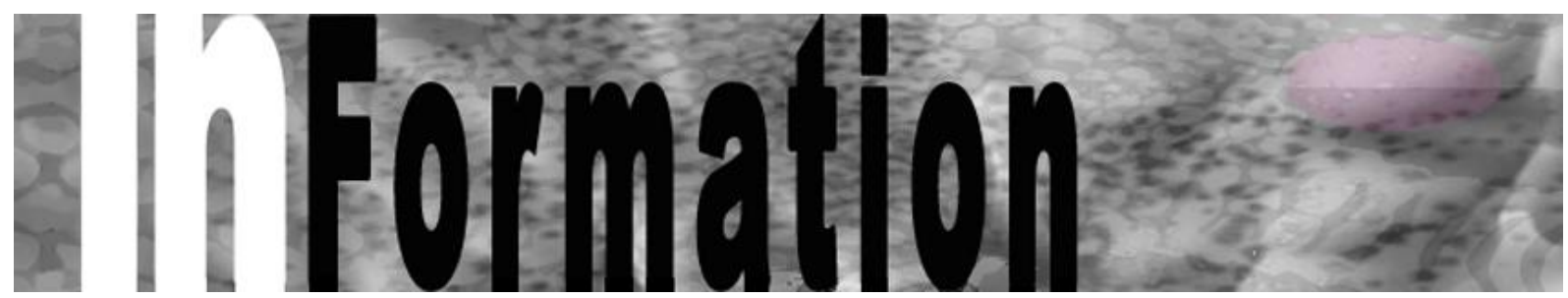

\title{
Nordic Journal of Art and Research
}

\section{Med hvilken rett blir din sigøynerhistorie min fortelling? Om innsamlings- og fortolkningsproblematikk}

\author{
Heidi Dahlsveen, ${ }^{1}$ Rikke G. Gjærum ${ }^{2}$ \& Thor-André Walløe ${ }^{3}$ \\ Høgskolen i Oslo og Akershus
}

Sammendrag: Artikkelen utforsker hvilke fortellinger vi velger å fortelle om andre, og med hvilken rett andres narrativer blir fortellerens eget materiale. Vi diskuterer derfor selve innsamlings- og fortolkningsproblematikken som inngår i et kunstdidaktisk arbeid når man både er forsker, fasilitator og forteller i et prosjekt som omhandler marginale og sårbare grupper i samfunnet. Artikkelen bygger på produksjonen «Romfolk - et folk i veien» som ble spilt under Festspillene i Nord-Norge. Hensikten med produksjonen var å skape en forestilling basert på sigøyneres tradisjonsfortellinger og beretninger om hvem sigøynere selv opplever at de er. Fortellingene og innsikten de rumenske informantene bidro med, ble av artikkelforfatterne fortolket som immateriell kulturarv og formidlet gjennom å anvende teater som ledd $\mathrm{i}$ en anti-stigmatiseringsprosess mot romfolk.

Emneord: Fortelling, anvendt teater, romfolk, sigøyner, identitet, narrativ, marginalitet.

\footnotetext{
${ }^{1}$ Høgskolen i Oslo og Akershus, Fakultet for teknologi, kunst og design, Institutt for estetiske fag. E-mail: heidi.dahlsveen@hioa.no

${ }^{2}$ Høgskolen i Oslo og Akershus, Fakultet for teknologi, kunst og design, Institutt for estetiske fag. E-mail: rikke.gurgens@hioa.no

${ }^{3}$ Høgskolen i Oslo og Akershus, Fakultet for teknologi, kunst og design, Institutt for estetiske fag. E-mail: elevathor@me.com
} 


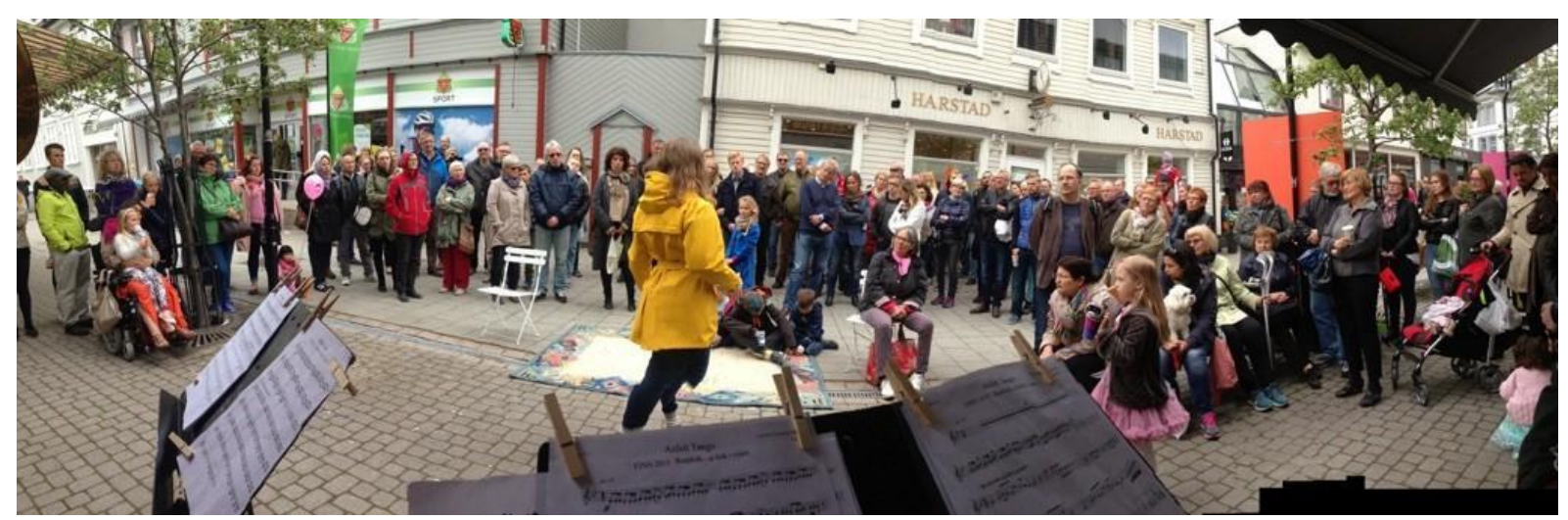

Forteller i aksjon i gågaten i Harstad, foto: Ole Thomas Gjærum.

\section{Introduksjon}

I juni 2015 sto vi i en sommergate i Harstad for å formidle fortellinger til et tilfeldig forbipasserende festspillpublikum som etter hvert stilte seg opp i en halvsirkel rundt oss. Fra himmelen skrek måkene i utakt med fortellerstemmen. Mellom fortellingene som ble fortalt, ble det spilt såre men fengende balkanske rytmer. Fortellingene vi fortalte, var ikke våre historier, det var beretninger vi hadde hørt. Mellom fortelling, rytme og publikums anerkjennende lytting, gikk en liten ung kvinne rundt med en kopp. Ingen så henne. Maria var lavmælt, hun på oss og vandret videre.

Produksjonen «Romfolk - et folk i veien» er knyttet til Norges ratifisering av UNESCOs konvensjon av 17. oktober 2003 om vern av den immaterielle kulturarven. Ifølge UNESCOs konvensjon defineres immateriell kulturarv som:

/.../ praksis, fremstillinger, uttrykk, kunnskap, ferdigheter - samt tilhørende instrumenter, gjenstander, kulturgjenstander og kulturelle rom - som samfunn, grupper og, i noen tilfeller, enkeltpersoner anerkjenner som en del av sin kulturarv (St.prp. nr. 73 (2005-2006), s.2).

\section{Forskningsmetodikk}

Forskningsdesignen som artikkelen bygger på, er kunstbasert (Haseman, 2006). Empirien består av en fortellerteaterproduksjon som er utviklet på bakgrunn av samtaler med studiens informanter. Vi har altså skapt en forestilling basert på observasjon av og intervju med sigøynere i Oslo (Saldaña, 20005), men forestillingen ble spilt i Harstad. Erfaringene med innsamlings- og fortolkningsproblematikken som inngikk i det kunstdidaktiske arbeidet vi skapte, er dermed fokus for denne artikkelen når vi spør oss selv: Hvilke fortellinger velger vi å fortelle om andre, og med hvilken rett blir andres narrativer fortellerens eget materiale?

Forskningsprosjektet kan deles i to faser. I første fase gjorde vi en etnografisk studie i Oslo i perioden 2013-2014 der gatebefaring, gruppeintervju og observasjon ble gjennomført (Denzin, 1997). I andre fase transkriberte og fortolket vi dataene fra innsamlingen, mens vi i tredje fase bearbeidet dataene og omskapte dem til et manus innenfor et gateteaterkonsept. Vi ønsket altså å samle inn tradisjonsfortellinger for å få ny kunnskap om hvem romfolk selv opplever at de er. Vi ønsket dermed å bidra til at sigøynernes tradisjonsfortellinger ikke forsvinner i takt med oppløsningen av deres kultur, slik det advares mot i rapporten Immateriell kulturarv i Norge: en utredning om UNESCOs konvensjon av 17. oktober 2003 om vern av den immaterielle kulturarv. 
I første fase fikk vi hjelp av Kirkens Bymisjon og IMKULT ${ }^{4}$ for å gjennomføre to befaringer i Oslos gater og et gruppeintervju med tre informanter. Vårt mål var å komme i kontakt med omreisende sigøynere som hadde fortellinger å fortelle. Dette møtet bød først og fremst på språklige utfordringer. I samarbeid med tolken fra Kirkens Bymisjon hadde vi vansker med å presist formidle vår intensjon til de menneskene vi møtte, fordi sigøynerne på gatebefaringen virket mer interessert i å fortelle om sin egen livssituasjon enn sin kulturs tradisjonelle fortellinger. De vi møtte, var rumenske tiggere som hadde reist til Norge for å tjene mer penger enn de gjorde i Romania. Informantene ønsket ikke å bli omtalt som romfolk, men som sigфynere. En eldre mann som forstod vår hensikt, svarte: «/.../ vi er for fattige til å fortelle». Han bekreftet altså UNESCO-rapportens varsko om sigøynerkulturens oppløsning i vår tid: «Mange eldre [sigøynere] er /.../ bekymret for det de oppfatter som en oppløsning av kulturen fordi tradisjonene ikke blir godt nok overført til yngre generasjoner».

Når en faktor som fattigdom forhindrer en kulturoverføring til yngre generasjoner, står de tradisjonelle fortellingene i fare for å forsvinne fordi det ikke foreligger skriftlig dokumentasjon verken på eksistensen av, eller innholdet i disse fortellingene. Det er kjent at omreisende sigøynere som folkegruppe er preget av analfabetisme, og i likhet med primary orality-kulturer tradisjonelle fortellinger muntlig overført fra en generasjon til den neste. Professor Walter Ong definerer begrepet primary orality som kulturer bestående av «/.../ persons totally unfamiliar with writing» (Ong, 1982, s.16).

Når informantene fortalte om hvordan fattigdommen og analfabetismen preget deres familie, opplevde vi en endring i vårt perspektiv og forskerblikk. Vi forholdt oss ikke lengre til sigøynere som en gruppe eller som statistikk, men til enkeltmenneskene vi møtte som representanter for en utdøende kultur. Dermed ble vårt personlige møte med informantene en viktig del av fortellerforestillingen vi skapte, noe som er i tråd med Etnoteaterets prinsipper om å skape teater basert på livshistorier og personlige møter (Saldaña, 2005). Møtet ble også avgjørende for valg av andre tradisjonsfortellinger vi fant frem til i forestillingsarbeidet. Vi valgte å kalle forestillingen «Romfolk - et folk i veien», uten spørsmålstegn, for å skape undring og refleksjon hos et potensielt publikum. Hvilket perspektiv ville forestillingen presentere?

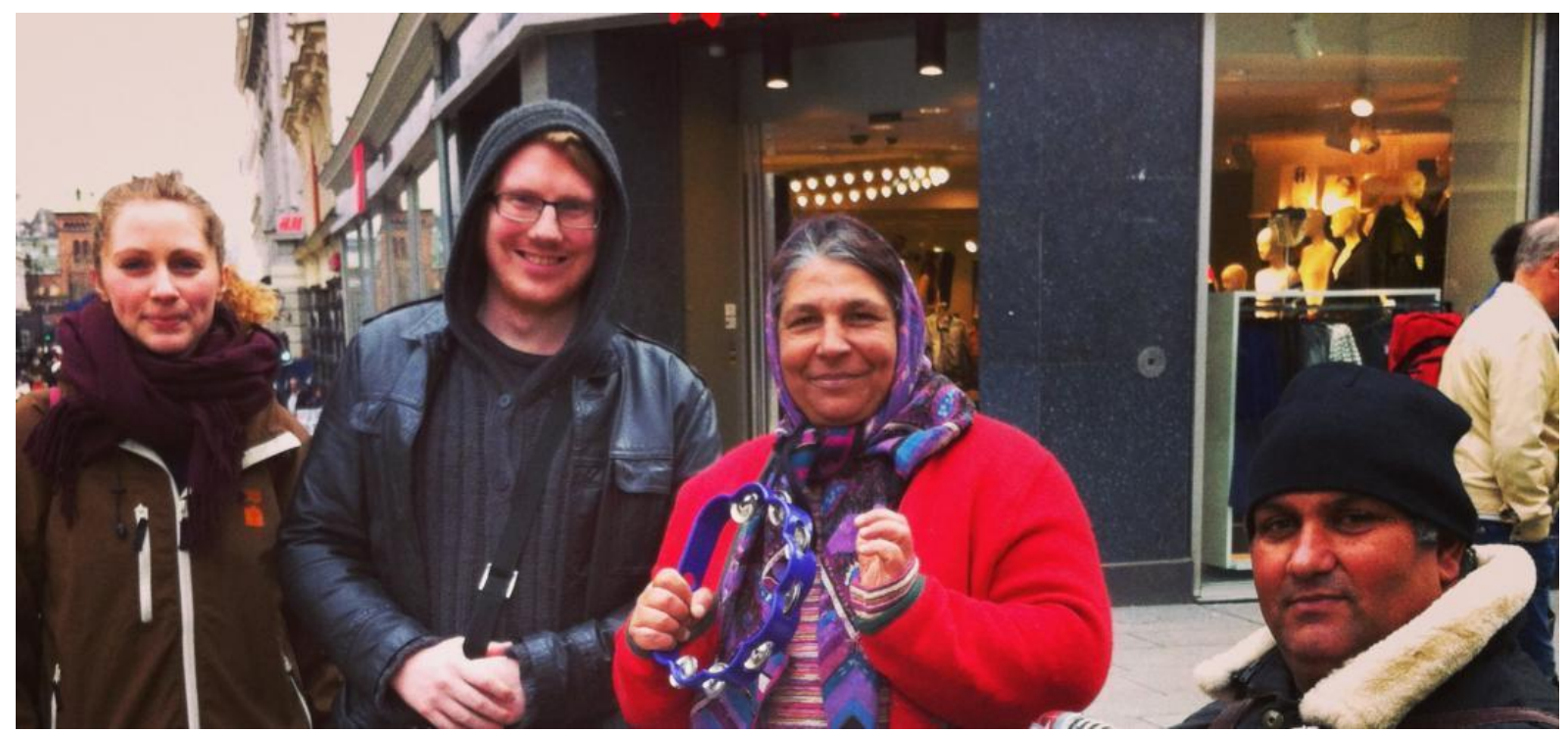

Gatebefaring i Oslo, foto: Sara Birgitte Øfsti.

${ }^{4}$ https://blogg.hioa.no/imkult/ 


\title{
Utvalg og fortolkning
}

Fortellerinnsamlingen ble gjort i prosjektets andre fase etter gatebefaringene. Vi gjorde intervjuavtale med tre informanter som uttalte at de anså seg som bærere av sin kulturs tradisjonelle fortellinger. Møtet mellom dem og oss fant sted i Tøyen kirke der Kirkens Bymisjon har sine lokaler, og formen var gruppeintervju (Amdal, 2002). Vi ønsket i utgangspunktet å starte intervjuet med en fortelling fra vår egen kultur for å ikke legge byrden med å begynne samtalen over på våre informanter. Vi har i denne sammenheng mer tro på dialogisk erfaringsutveksling snarere enn et tradisjonelt strukturert intervju som virker noe mer monologisk. Dermed ville vi gi informantene det vi ønsket fra dem; et innblikk i en fremmed kultur. Sett fra deres ståsted var vel vi de såkalt «andre»?

På tross av vår intensjon gikk ikke intervjuet helt som planlagt. Vi møtte de tre informantene, to menn og en kvinne, som alle hadde fortellinger de ønsket å formidle ved hjelp av en tolk, og dette skulle foregå innenfor en knapp tidsramme på omtrent en time. Vår egen tradisjonsfortelling ble det derfor dessverre ikke tid til. For før noe annet kunne skje, var kvinnen nødt til å henvende seg til de to mennene for å spørre om lov til å fortelle. Dette var en del av deres tradisjon, fortalte de. Den første historien informantene formidlet, var denne:

\begin{abstract}
En sigøyner hadde et lite hus og mange barn. En dag han kom hjem, kom han hjem full. Han kranglet med sin kone, slo henne. Hun ble værende på grunn av barna. Slik er sigøynerkvinner, de forlater ikke sine barn. Hun tenkte at han ville bli bedre i fremtiden. En dag ble hun sur. Hun tok toget og forlot han. Hun stoppet i en by, Calafat. Hun var en veldig vakker sigøyner. På gaten ble hun stoppet av en gentleman, en stilig mann med flotte klær. Han sa til henne: «Du er en veldig vakker kvinne, vil du ikke prate litt med meg?» Til slutt overtalte han sigøynerkvinnen til å gifte seg med han. Han tok henne med seg til sitt hjem, et palass med en veranda. Sigøynerkvinnen bodde sammen med han en, to, tre, fire, fem måneder. Nå gråt barna etter sin mor, og når faren kom hjem etter jobb spurte de han: «Far, hvor er mor?» Han tok barna med seg, for han hadde hørt et rykte om at hun var i Karapat by. Vandrende rundt i byen så han verandaen. Han så henne på verandaen. Da hun så ned, så hun sin mann og deres barn, og hun sa til den stilige mannen: «Se, der er min mann og mine barn». Mannen svarte: «Be han komme hit». «Hva er din historie, hva har skjedd med deg?» Han svarte «Gi min kone tilbake til meg, du ødelegger mitt hjem». Han sa at kvinnen var hans sigøyner. Gentlemannen visste ikke at hun var sigøyner. «Hun er ingen sigøyner», og han sa til ektemannen: «Hvis hun snakker sigøynernes språk, romani, så vil jeg gi henne tilbake. Hvis hun ikke snakker romani, så vil jeg skjære over strupen din fordi du er en løgner». Ektemannen snakket med sin kone på romani. Han forsøkte å overbevise henne om å komme hjem til sine barn. Han ville stoppe å drikke og oppføre seg bra. Kvinnen sa til gentlemannen på rumensk: «l stedet for å bo med deg i ditt palass vil jeg heller leve i mitt falleferdige hus med noen jeg bryr meg om». Hun hadde barn, og dette varmet hennes hjerte. Stoppet han å drikke? Vi vet ikke. Hun vende hjem for sine barns skyld, ikke for sin manns skyld.
\end{abstract}

Av de fortellingene vi valgte å fortelle i forestillingen ble denne første ikke inkludert i manus. I utvalgsprosessen gjorde vi klare etisk funderte valg, fordi vi ikke ville tilføre ytterligere stigma til sigøynerne i Norge. Vi ville ikke bidra i den negativt ladede medierte debatten om sigøynere som en folkemasse uten nyanser. Vi ønsket derimot å formidle fortellinger som gav gjenklang av vårt personlige møte, snarere enn det vi stadig blir møtt med i avisoverskrifter og bilder fra gata. Vårt ønske var å formidle fortellinger som samsvarte med våre opplevelser i møtet med informantene under befaring og under intervju (Saldaña, 2005). Det er viktig å presisere hvilken fare det innebærer å bare støtte seg til personlige opplevelser som dokumentasjon av intervju, siden det kan medføre en for subjektiv erindring preget av glemsel eller fordommer (Kvale 2009, s.188). Dermed ble dokumentasjonen av lydopptak av gruppeintervjuet, som etter hvert tok form som skriftlige transkripsjoner, sentralt for utviklingen av forestillingen. Fortellingene, slik de ble formidlet av sigøynerne, ble først oversatt til engelsk av en tolk. Denne versjonen ble tatt opp på lydbånd og deretter transkribert. Til slutt ble fortellingene oversatt til norsk. Det innebærer tre fortolkninger av fortellingen når man beveger seg fra primærkilde til dokumentasjon, forstått som forskningsdata. 
I det første leddet, fra kilde til tolk, foregikk en språklig fortolkning fra romani til engelsk. I det andre leddet, fra tolk til lydopptak, mistet man derimot det fysiske nærværet slik at lydbildet måtte fortolkes ved hjelp av hukommelsen og fantasien. I det tredje leddet, fra transkripsjon til oversettelse, foregikk en ny språklig fortolkning fra engelsk talespråk til norsk skriftspråk. Det skjedde altså en omfattende endring av det empiriske materialet fra kilde til dokumentasjon, der man kan hevde at fortellingens kulturelle tilhørighet allerede hadde begynt å forflytte seg. Fortellingene som dermed foreligger i skriftlig dokumentasjon i transkripsjonen, er altså ikke lenger en monokulturell konstruksjon, men nye fortellinger skapt i møtet mellom «dem»og «oss». Det er dermed problematisk å påstå at dette prosjektet faktisk direkte bevarer sigøynernes kultur. Det motarbeider heller den totale oppløsningen av denne kulturen. En måte å betrakte fortolkingen på er at vår rett til å formidle sigøynernes tradisjonelle fortellinger, faktisk styrkes gjennom det personlige møtet og fortolkningen, faktisk styrkes, fordi vi ut fra de tre fortolkningsleddene kan betrakte oss selv som medskapere av tradisjonsfortellings-formidling i en kunstdidaktisk ramme.

For å forstå den verden vi lever i, de fortellingene vi lytter til og de erfaringene vi velger å dele med andre, må vi alle tolke og vi inngår dermed i hermeneutiske spiraler der førforståelsen endres i møtet med andres referansebakgrunner og horisonter (Gadamer, 2010). Vi har fortolket informantenes fortellinger, de har tolket våre spørsmål og undringer og vi er alle dermed «/.../ meningsskapende og tegntolkende vesen som av den grunn har behov for å forstå seg selv og den virkelighet som det står i forhold til» (von der Fehr, 2008, s.58).

\section{Begreper å begripe med}

Men hva legger vi i betegnelsen «romfolk» slik det blir brukt i norsk offentlighet? Hvordan tolker vi dem vi omtaler som romfolk og hva signaliserer egentlig vår begrepsbruk? Betegnelsen er en medieskapt gruppebetegnelse som i hovedsak brukes om reisende folk fra Romania og Bulgaria. Men romfolk brukes også om fattige som i årene etter EU-utvidelsen i 2007 har reist fra Øst-Europa til Vest-Europa. En stor del av dem tilhører minoritetsgruppa rom, men ikke alle. I Norge er rom den offisielle betegnelsen på den folkegruppa som tidligere ble omtalt som sigøynere og som marginaliseres i det norske samfunnet. Romfolk er en gruppe som fremstår som samlet i den kollektive fortolkningen, men som reelt sett består av ulike individer med forskjellige livserfaringer og et mylder av fortellinger om levd liv. Vi mener at de begreper vi bruker, faktisk farger fortolkningen vår, og derfor spurte vi informantene hvilket ord de foretrakk at vi brukte om dem. Informantene sa eksplisitt at de ikke ønsket å bli omtalt som romfolk, men som sigøynere. Vår erfaring med å samle inn fortellingene fra sigøynere er at man i utgangspunktet har en tendens til å distansere seg fra andre mennesker ved å benytte begreper som grupperer mennesker i samlende kategorier, for eksempel romfolk, slik at enkeltindividet ikke blir synlig for oss. Dermed forsvinner det humane, det som kunne appellere til vår empati, i skyggen av samlekategoriens såkalte egenart. På gatebefaring og i gruppeintervjuet opplevde vi imidlertid at vi kom på baksiden av merkelappen «romfolk».

Et annet begrep som er vesentlig i denne artikkelen, er begrepet «fortelling». Det henviser til et bredt sammensatt felt med mange diskurser. Filosofen Alasdair MacIntyre mener at det er $\ll / \ldots /$ gjennom fortellingene vi lærer våre samfunnsmessige roller å kjenne, og at det er de rollene vi innehar, som gir form og retning til handlingene våre» (Hovland, 2002, s. 67). Dette vil si at fortellingen er sentral for å forstå hvordan verden er innrettet. Ifølge den amerikanske filosofen Mark Johnsen møter vi fortellingen gjennom våre foreldre som små barn, og disse fortellingene skal bidra til forståelse av livserfaringer (Hovland, 2002). Vi tar selv fort i bruk fortellergrepet når vi gjør forsøk på å beskrive hva som skjer i 
livene våre, og dermed kan man definere «fortellingen» som den mest utbredte rasjonelle forklaringsmåten (Hovland, 2002). Fortellingen er et grep vi bruker gjennom hele livet fordi vi søker svar på hvem, hva og når. McLean og Pasupathi (2011) hevder at mennesket har en narrativ identitet, og at denne identiteten baserer seg på hvordan vi skaper mening ut av hendelser i livet. Den narrative identiteten er vår livsfortelling som består av utvalgte hendelser i vårt liv. Gjennom å fortelle om hendelsene skapes det en sammenheng mellom disse (McLean \& Pasupathi, 2011). Hvordan vi rekonstruerer fortiden i samspill med signifikante andre, er viktig for å utvikle narrative ferdigheter. Marianne Horsdal mener at i vårt moderne samfunn er identiteten en narrativ konstruksjon, en fortelling som blir til i møtet med andre, noe vi selv erfarte i datagenereringen til prosjektet. Fortellinger blir til i ulike kontekster som i familier, blant kollegaer og venner (Horsdal, 2011). Vi vet at det å fortelle en fortelling muntlig er å gjøre hendelser umiddelbart nærværende i fantasien. Ifølge Lundby (2003) impliserer bruk av begrepet «det narrative» at det er en relasjon til stede, altså at noen forteller noe til noen. Antropologen Myerhoff understreker hvor viktig denne relasjonen er: «/.../ the pathos of the absent listener is the deprivation of an individual's birthright» (Myerhoff, 2010, s. 21). Relasjonen er viktig fordi den former fortellingen, og dette aspektet viste seg å bli helt essensielt $\mathrm{i}$ vårt prosjekt. Formprosessen er en nøkkelfaktor som peker på nettopp det sosiale aspektet. Vårt prosjekt var å bruke fortellinger i en fortellerforestilling, og muntlig fortellerkunst er en intersubjektiv handling hvor tre parter er aktive: fortelleren, fortellingen og lytteren (Magurie, 2015).

\section{Dramaturgi og det sosiale båndet}

Vi vil nå gå i dybden på de fortellingene vi valgte å fortelle og studere måten vi valgte å presentere dem på, for deretter å diskutere med hvilken rett en informants historie blir fortellerens fortellermateriale. Skjematisk sett kan forestillingens program på totalt åtte scener, fremstilles på følgende måte:

\begin{tabular}{|c|c|c|}
\hline Nr. & Fortelling & Innhold \\
\hline 1 & Au o zi buna & $\begin{array}{l}\text { En personlig fortelling om møtet med sigøynere og innsamlingen av deres tradisjonelle fortellinger. For å fange } \\
\text { folks oppmerksomhet i gågaten der vi stod, ble forestillingen innledet med energisk og lystig balkanmusikk, } \\
\text { før fortellingene tok over. Au o zi buna ble delt inn i to deler med et musikkinnslag i midten, der første delen } \\
\text { handlet om befaringen foretatt i Oslos gater og den andre handlet om møtet i Tøyen kirke. }\end{array}$ \\
\hline 2 & Moroy & $\begin{array}{l}\text { Denne fortellingen handler om en kvinne som dør i barsel, og hennes gjenferd hjemsøker så bygden hun kom } \\
\text { fra. Når hennes mann og deres barn fatter mistanke åpner de graven hennes og ser at liket har forandret } \\
\text { liggestilling og at det er kloremerker på innsiden av kisten. De gjennomfører en ritualistisk brenning av liket, } \\
\text { noe som gjør at besettelsen, eller Moroy, forlater hennes sjel og hun slutter å hjemsøke bygden. Fortellingen } \\
\text { ble under forestillingen innledet med et stykke balkanmusikk som var ment å frembringe en underfundig } \\
\text { stemning. }\end{array}$ \\
\hline 3 & Kidnappet & $\begin{array}{l}\text { Denne fortellingen handler om en rikmannsdatter som rømmer sammen med en fattig sigøynergutt som hun } \\
\text { møter på en sigøynerfest. Hun innser at hun finner mer kjærlighet i et liv som fattig enn som rik. Fortellingen } \\
\text { ble innledet med et stykke musikk som var ment å være i sigøynerfestens landskap, med høyt tempo og en } \\
\text { oppløftende melodi. }\end{array}$ \\
\hline 4 & Prestens griser & $\begin{array}{l}\text { I denne fortellingen klarer en fattig sigøynerfamilie å lure sin rike nabo, presten. Etter å ha gitt presten et godt } \\
\text { måltid som han lover at Gud vil belønne dem for, slakter sigøynerne prestens flotteste gris som de så lager et } \\
\text { nytt måltid av. Når presten oppdager at hans gris er blitt slaktet, blir han rasende, men når han konfronterer } \\
\text { sigøynerne så blir han selv konfrontert med sine egne lovord. Presten finner ingen motargumenter, og de } \\
\text { forsones ved å dele måltidet. Fortellingen ble innledet og avsluttet med balkanmusikk. }\end{array}$ \\
\hline 5 & Tante Sigrunn & $\begin{array}{l}\text { En personlig fortelling om barndom og møtet med det som på } 1970 \text { - tallet ble kalt «Signøynere». Fortellingen } \\
\text { fungerte som en inngang til noe eksotisk, der man følte seg mer hjemme hos sigøynerne enn hos seg selv. }\end{array}$ \\
\hline 6 & $\begin{array}{l}\text { Kongen som ville ha } \\
\text { en kone med to } \\
\text { vaginaer }\end{array}$ & $\begin{array}{l}\text { Kilden til fortellingen er ukjent. Den handler om en konge som trenger en dronning med to vaginaer. En fattig } \\
\text { kvinne later som hun har det og gifter seg med kongen. Kongen trenger å låne den ene vaginaen når han skal } \\
\text { ut på reise. Dronningen fanger en fugl, later som om det er hennes ekstra vagina og gir kongen beskjed om å } \\
\text { ikke miste denne. Det gjør han. Han ber dronningen om tilgivelse og dermed forsones de i sannheten. }\end{array}$ \\
\hline
\end{tabular}




\begin{tabular}{|l|l|l|}
\hline 7 & Jack og eselet & $\begin{array}{l}\text { Fortellingen er muntlig overlevert av Duncan Williamson, skotsk traveller (omreisende). Jack går igjen som } \\
\text { hovedperson i mange fortellinger, og her ønsker han et samleie med eselet, siden han ikke finner en elskerinne. } \\
\text { Jack ber en naken kvinne om å holde eselet for han. }\end{array}$ \\
\hline 8 & Jenta som var så stor & $\begin{array}{l}\text { Fortellingen er satt sammen av fortelleren av et rumensk og norsk folkeeventyr. Fortellingen handler om en } \\
\text { kvinne som har så stor vagina at hun kan drive en rekke møller. Hennes far bestemmer seg for å finne en } \\
\text { passende ektemann. }\end{array}$ \\
\hline
\end{tabular}

I forestillingen valgte vi fortellinger som vi mente et gågatepublikum på en kulturfestival kunne gjenkjenne, samtidig som vi ønsket å formidle et variert og nyansert repertoar av fortellinger for å vise at sigøynere er like sammensatte mennesker som oss. Derfor valgte vi å produsere de åtte scenene modellen over beskriver. Vi ønsket å fremme ulike følelsesmessige tilstander, fra ubehag ved det skumle til lettelse og glede ved det humoristiske. Vi tok også i bruk personlige fortellinger som beskrivelser av møtet med Romfolket, for å gi en klart perspektivert inngang til materialet (Okpewo, 2003). Vi valgte ut fortellinger knyttet til de positive særtrekkene ved sigøynerkulturen som vi ønsket å formidle. Dette ble gjort både for å ivareta deres tradisjonsfortellinger og immaterielle kulturarv, og for å bidra til å skape et annet blikk på sigøynere som i offentligheten ofte ensidig blir forstått som tiggende romfolk. Gjennom analysen av de tre fortellernes egne fortolkningsprosesser og transformasjoner av fortellermaterialet, kom vi frem til fem fenomen som ble førende i utvalgsprosessen til forestillingen. De fem fenomenene var: fattigdom som fortellermotivasjon, kjønn som en talende røst, erotikk som isbryter med publikum, kjarlighet som kulturell bro mellom minoritet og majoritet og grøss som driv $i$ forestillingen. Disse fem fenomenene er representert i de åtte scenene og ble brukt som en tematisk tråd da vi utviklet dramaturgien til forestillingen.

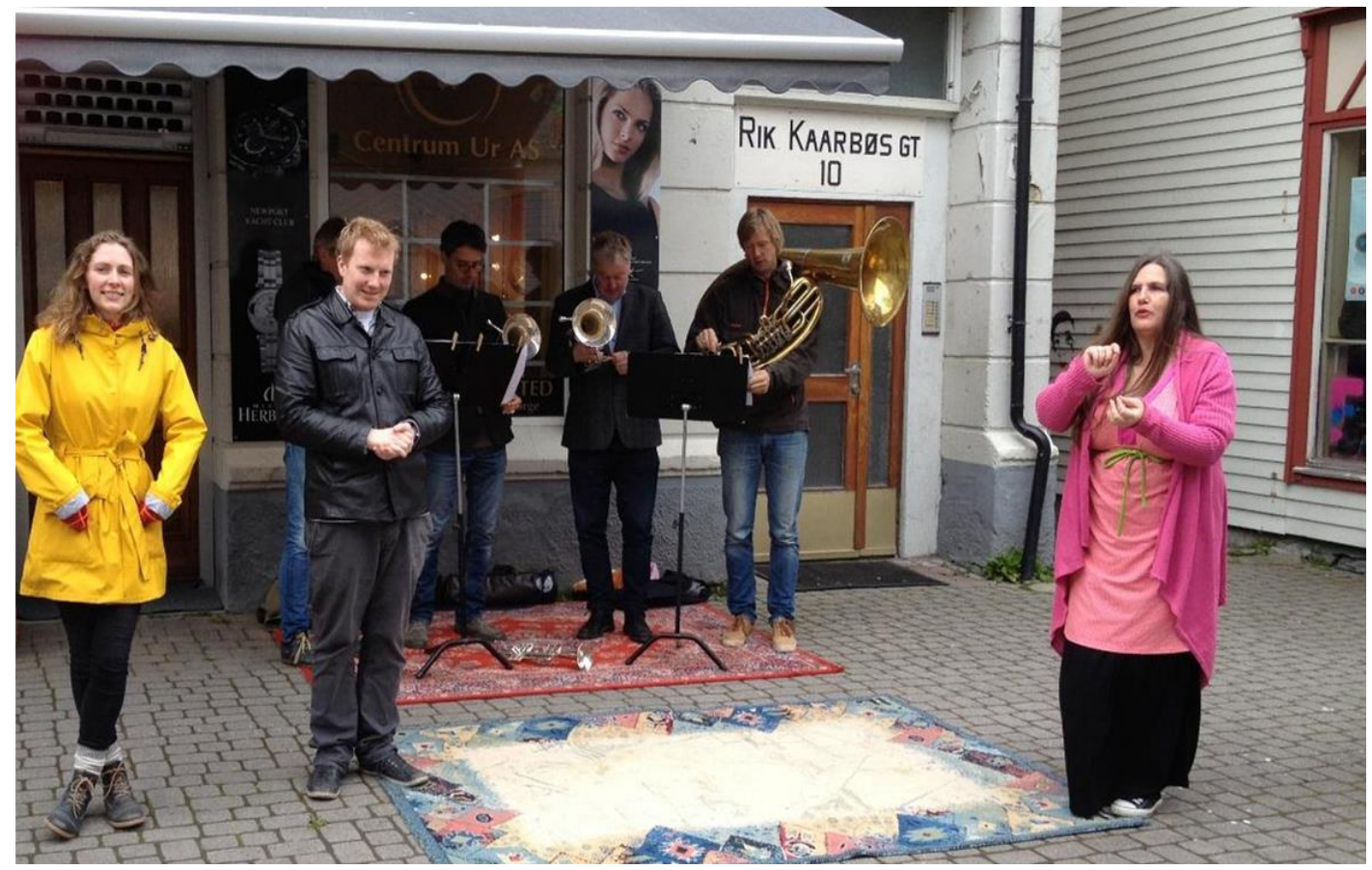

Fortelling i gata Foto: Juliane Sukkestad

I forestillingsproduksjonsprosessen arbeidet vi videre med en erkjennelsesskapende dramaturgisk inngang, inspirert av performanceteoretikeren Richard Schechner (1981). Vi ønsket at forestillingen skulle bli fortellernes, musikernes og publikums relasjonelle møte i gågata. Vi ville skape det sosiale båndet mellom dem, forstått gjennom Schechners begrep «rasa» og «bhava» som kan sammenlignes med det å lage og dele et måltid (Schechner, 1981). Rasa, som kan oversettes med «krydder», er det 
vokabularet i en forestilling som blir behersket av utøveren (Schwartz, 2004), mens bhava er den følelsesmessige erfaringen deltakerne får i løpet av forestillingen. Tanken er at den følelsesmessige erfaringen skal føre til en endring hos publikum (Schwartz, 2004). Det var nettopp en slik holdningsendring eller gryende bevisstgjøring vi ville å skape med «Romfolk- et folk i veien».

Vi tok derfor også i bruk erotiske fortellinger for å vekke publikums interesse ved å skape noe uventet, vågalt og bruke humor i møtet med et nordnorsk publikum. Vi hadde tro på at disse fortellingene lett kunne fortelles videre av lytterne. Vi var i produksjonsprosessen bevisste på at når man lytter til en fortelling, er det to aktiviteter som pågår. Man får både ny kunnskap og tolker denne nye kunnskapen i lys av egne erfaringer (Braid, 1996, 6). Man kan da snakke om en lyttertranse eller lytterens nærvær, det vil si en «"/.../ discrete altered state of consciousness»" (Sturm, 1999). Myerhoff (1999) beskriver lytting som en tilstand av å være og å ikke være, der man altså er i flyt med det som skjer, samtidig som man er bevisst seg selv. Vi vet at muntlig fortellerkunst har sin dramaturgiske opprinnelse i tette fellesskap der lytteren kjente fortellingen (Lord, 2000). Fortellerens kunst besto da i å skape denne fortellingen på en ny måte for å gi lytteren en ny opplevelse (Lord, 2000). Dette fellesskapet har vi ikke lenger på samme måte i vårt samfunn, og derfor må vi ta i bruk ulike metoder for å skape kontakt med lytterne, f.eks. gjennom erotiske fortellinger på gata i Nord-Norge.

\section{Intertekstualitet}

Intertekstualitet er grep som fortellere tar i bruk bevisst og ubevisst. Folkeeventyr er ofte variasjoner over samme struktur (Hodne, 1998), og fortellere studerer gjerne flere variasjoner av samme fortelling når de arbeider fram sin egen variant av fortellingen (Dahlsveen, 2008). Fra vår egen kultur kjenner vi til historier om den fattige gutten som får prinsessen og halve kongeriket. En fortelling vi ble fortalt på Tøyen under gruppeintervjuet, kan betraktes som dens rake motsetning, der en rikmannsdatter flykter fra sin familie for å leve sammen med en fattig sigøynergutt:

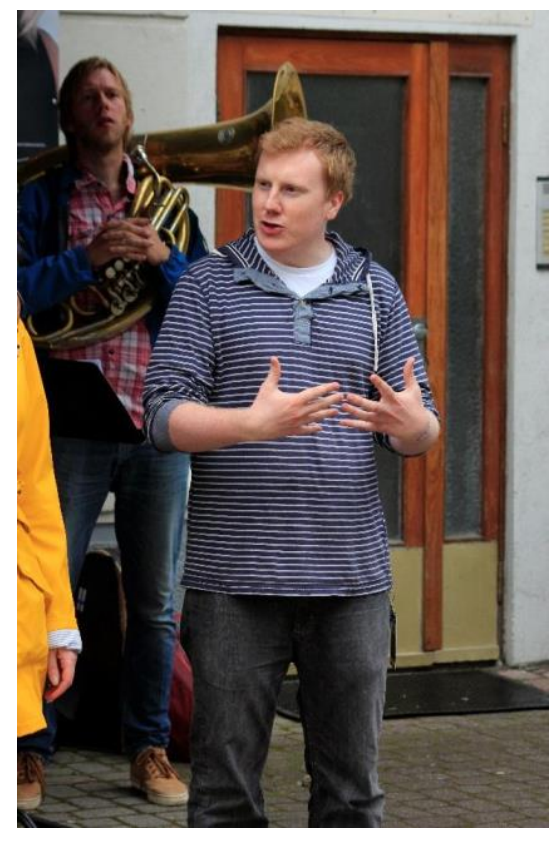

Thor Andre Walløe forteller. Foto: Juliane Sukkestad 
Det var en gang en vakker jente. Hun var datter av en rik familie og hennes far var general i den nasjonale hær. Jenta hadde hørt om en stor fest som skulle holdes i bygda. Det var en sigøynerfest, en tradisjonell sigøynerfest med musikk og dans. Jenta lurte seg ut om kvelden og dro avgårde til bygda. På festen traff jenta den flotteste gutten hun noensinne hadde sett, en sigøynergutt. Dette er sant. De danset, de sang, de holdt omkring hverandre og forelsket seg i hverandre. Jenta sa at hun skulle ønske de to kunne gifte seg, og med det tok gutten jentas hånd og spurte om hun ville gifte seg med ham. Han spurte henne om hun ville bli med ham hjem. De gikk og gikk og jenta lurte på hvor dette huset hans var og når de ville være framme, for hun begynte å bli sår i bena. De hadde gått i tre dager og fremdeles ikke kommet frem. Gutten svarte at der, litt lenger fremme mellom dalene, omringet av blomster, der står tre telt. Det er mitt hjem, et telt. Hans mor kom ut fra det ene teltet og ønsket jenta velkommen. Gutten introduserte jenta som sin kone. Jenta spurte sin svigermor om det var noe hun kunne hjelpe med. Svigermoren ga henne en konkylie til å spå fremtiden i og en malerkost til å male med. Jenta tenkte for seg selv at hun hadde gitt opp sengen sin hjemme i villaen for å sove i røyken fra bålet der maten ble laget. Hun hadde byttet ut de store tømmerstokkene som villaen var bygget av med kvister i skogen. En gang luktet hun av god parfyme, nå luktet hun røyk. Men nå hadde hun likevel noe mer verdifullt, et hjerte fullt av kjærlighet.

I likhet med fortellingen om vold som vi valgte å ikke videreformidle, handler også denne fortellingen om en kvinne som velger fattigdom og sigøynerlivet fremfor rikdom, om enn med en lykkeligere slutt. På grunn av den positive utgangen og den noe dissonante moralen i fortellingen ønsket vi å bearbeide og videreformidle denne fortellingen. Bearbeidelsen betød i dette tilfellet å dekontekstualisere og rekontekstualisere meningsinnholdet i fortellingen (Kvale, 2015). Dette gjorde vi ved å gjenfortelle fortellingen flere ganger, men med stadig strammere tidsbegrensninger (Dahlsveen, 2008). Hensikten var å konsentrere fortellingens viktigste og mest grunnleggende handlingsforløp. En dekontekstualiseringen vil alltid representere en høyst personlig fortolkning som dermed gir ulikt resultat basert på fortolkerens kulturelle bakgrunn, kjønn og estetiske preferanser.

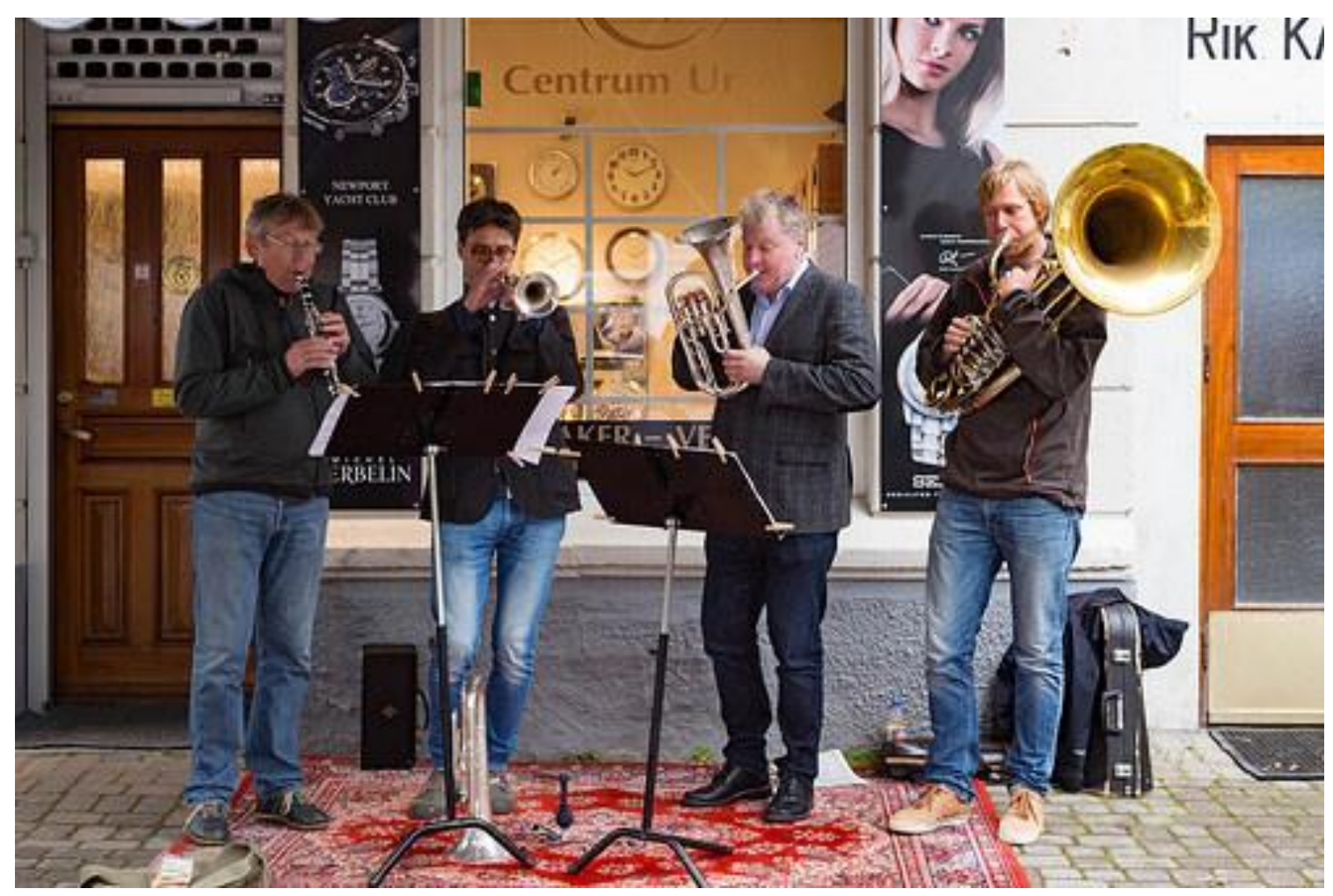

Orkesteret Kalabalik spiller opp. Foto: Rikke Gürgens Gjærum. 


\section{Etiske refleksjoner}

Det er viktig å se prosjektet «Romfolk - et folk i veien» $\mathrm{i}$ et kritisk lys, siden slike anvendte teaterprosjekter har etiske aspekter man ofte i ettertid ser klarere enn man evnet å gjøre i produksjonsfasen. Disse aspektene bør derfor løftes frem for å bidra til åpenhet og kunnskapsgenerering på dette kunstdidaktiske feltet. Vi velger å se på fem sentrale dilemmaer som vi opplevde i utviklingen og gjennomføringen av prosjektet: romantisering, eierforhold, kontekstualisering, valg av spillearena og dialog med publikum.

Å fortelle handler om å presentere valg. Vi la vekt på å skape et nyansert bilde av den marginale gruppen romfolk. For å klare det, valgte vi bort noen fortellinger. I ettertid spør vi imidlertid oss selv om vi ikke ved å velge bort deler vi finner upassende innenfor vår egen kulturkontekst, samtidig tar et grep som favoriserer et bestemt syn. Dette grepet kan relateres til den romantiske historiske perioden med nasjonaloppbygging i Norge da overordnede preferanser påvirket innsamlingen av våre folkeeventyr. I de franske salongene på 1600-tallet var eventyrformen en del av aristokratiets uttrykksform, spesielt blant de kvinnelige forfatterne (Solberg, 2007). De brukte eventyrformen til å speile adelslivet og få fram det de anså som undertrykkende, og det er også her vi finner det kjente eventyret: «Skjønnheten og udyret» (Solberg, 2007). En ganske lik variant av dette eventyret av Beaumont er skrevet ned fra Setesdal, men i overføringen fra det skriftlige grunnlaget til det muntlige versjonen har eventyret blitt skjematisert og forkortet. Det er en slik muntlig versjon Asbjørnsen og Moe valgte bort til fordel for variantene av «Kvitebjørn Kong Valemon». En av hovedgrunnene var at Asbjørnsen og Moe foretrakk det genuint norske, de var aktører i nasjonsbyggingen, og inspirert av brødrene Grimm kunne de ikke inkludere noe som representerte det franske aristokratiet (Solberg, 2007). Dessuten var «Skjønnheten og udyret» opprinnelig hentet fra en skriftlig litterær tradisjon og ikke den muntlige fortellertradisjonen der man fokuserte på det mytiske opphavet for å formidle en «nasjons fortid.» Dersom vi går tilbake til våre egne valg i dette prosjektet, brukte vi ikke da implisitt det vi anså for å være majoritetens syn for å fremme enkelte fortellinger framfor andre, eller innebar våre bortvalg en reell nytenkning om den marginale gruppen vi arbeidet med? Dette er et spørsmål vi fremdeles stiller oss.

Vi brukte personlige fortellinger som innganger til forståelse av de fortellingene vi fortalte. På den ene siden ønsket vi å heve den kunstneriske kvaliteten gjennom å ta i bruk oss selv som fortellere, samtidig som vi ønsket å ufarliggjøre møtet med sigøynere. For Okpewho som har studert tradisjonelle fortellere i Nigeria, er nettopp den personlige inngangen nødvendig for en kunstnerisk opplevelse. Hans observasjoner viser hvordan en mer kunstnerisk og ikke-personlig internalisert dimensjon faktisk kan komme i veien for fortelleropplevelsen og risikere å skape en kløft mellom forteller og lytter. Okpewo hevder at det kan være en kamp å få lytteren inn i et magisk univers i dag, slik de tradisjonelle fortellingene krever: «"/.../the artistic success of tales in the oral tradition depends, to a certain extent, on the degree to which a narrator can internalize the detail of his or her account»" (Okpewo, 2003, s. 223). Slik sett kan faktisk den personlige relevansen være en betingelse for at den tradisjonelle fortellingen skal bli husket som en kunstnerisk opplevelse, i betydningen estetisk erfaring (Dewey, 1934). Okpewo mener at det er en akseptert praksis når personlig forankring gir fortellingen meningsfull betydning i et fellesskap, fordi fortellingen da blir et vitne med relevans for fellesskapet.

I samtale med lytterne etter forestillingene kom det frem at enkelte opplevde de personlige fortellingene som en overkompensasjon, romantisering og eksotifisering av romfolket. Vi brukte kanskje for mye språkets poetiske funksjon, framfor den referensielle funksjonen der vi beskriver en mer reell kontekst (Jakobsen, 1960). Retrospektivt ser vi også at superlativene ble flittig brukt for å kompensere for ordet «sigøynere», som vi var redde ville skape negative reaksjoner hos publikum. På 
tross av at de selv ønsker å bli kalt sigøynere fremfor romfolk, var dette vår måte å signalisere til publikum at vi ikke tilla ordet en negativ konnotasjon. Kanskje var vi også bekymret for at publikum skulle se oss i et negativ lys, og at det derfor ikke bare handlet om hvilket forhold vi ønsket at publikum skulle ha til sigøynere, men også hvilket forhold de skulle ha til oss som formidlere. Ved å sensurere bort det vi oppfatter som negative aspekter ved deres kultur, og ved å romantisere bildet av dem og deres kultur, står vi i fare for å indirekte forherlige oss selv som etisk reflekterte fortellere.

I sigøynerfortellingen om «Jenta som var så stor» valgte fortelleren å sette fortellingen sammen med et norsk folkeeventyr, fordi hun ønsket en annen vri på fortellingen. Hun kjente til en fortelling fra egen kultur og valgte da å bruke intertekstualitet for skape en fortelling hun var komfortabel med, og på den måten få et eierforhold til fortellingen. Man kan forstå dette valget som at en godt dramaturgisk oppbygd fortelling foretrekkes framfor den originale muntlig overleverte versjonen. Lignende grep ble gjort $\mathrm{i}$ sigøynerfortellingen «Kidnappet», da det her var fortellerens vurdering at fortellingen slik den forelå i transkripsjonen, var dramaturgisk mangelfull i forhold til karakterenes indre motivasjon. En mulig forklaring på det var at protagonistens motivasjon ikke lot seg oversette, fordi hennes behov for å flykte fra rikdom til fattigdom er selvforklart innad i sigøynerkulturen men ikke i den norske kulturen. Fortelleren hadde derfor behov for å transformere fortellingen «Kidnappet», slik at den lettere kunne formidles til et norsk publikum.

Vi kan si at ønsket om «å dele et måltid» (Schechner, 1981) i fellesskapets nærvær, spilte en avgjørende rolle i forestillingen. Dette var også grunnen til at vi valgte å spille utendørs, fordi det er her de fleste har sitt møte med sigøynere, ute på gata der vi går forbi hverandre i hverdagen. Utendørsscenen skapte imidlertid utfordrende situasjoner for formidlingen en rekke ganger under forestillingene. Eksempelvis måtte forestillingen konkurrere med måkeskrik, varelevering og et turisthelikopter som med jevne mellomrom forstyrret forestillingen. Det var likevel vår visjon at forestillingen skulle foregå ute, være dynamisk og at publikum skulle få komme og gå som de ville. Vi mener også at man ved nettopp å spille utendørs, treffer et annet publikum enn det man møter inne i en teatersal. Vår erfaring er at man som utendørsforteller må forberede seg på det uforutsette. Det er ikke til å unngå at konteksten påvirker fortellerhendelsen.

Noe av vårt program besto av erotiske fortellinger som i seg selv tradisjonelt er tabu innenfor folkloren. Hensikten med det erotiske er ifølge vedaen å vekke glede og skape harmoni (Dahlsveen 2008). Gershon Legman, en av de få som har drøftet erotisk folklore, skal ha sagt at det er vold mot kvinner som er den egentlige pornografien (Cornog \& Perper 1999, s. 316). Han reagerte på at folkloren ikke hadde noen problemer med å dokumentere populærkulturens aggressive bilder, alt fra tortur til drap av barn, mens erotikken ble sensurert. Legman hever at det erotiske vitner om selve livets puls (Legman 1962 s. 200). De utvalgte erotiske fortellingene vi formidlet, var korte. De skulle vise en ukjent side ved temaet for forestillingen, og samtidig skulle de gi tilhørerne fortellinger de selv kunne fortelle videre. I ettertid spør vi oss likevel om ikke humor og erotikk fortalt av en forteller som ikke har samme opprinnelse som fortellingene, kanskje bringer fortellingene for langt bort fra den opprinnelige kulturkonteksten. Vi hadde et sterkt ønske om å skape dialog med lytterne, og laget derfor et inkluderende konsept rundt publikumsrollen. Dette innebar blant annet at vi delte ut en pappkopp til publikum, en kopp med bilder av tiggende romfolk: 


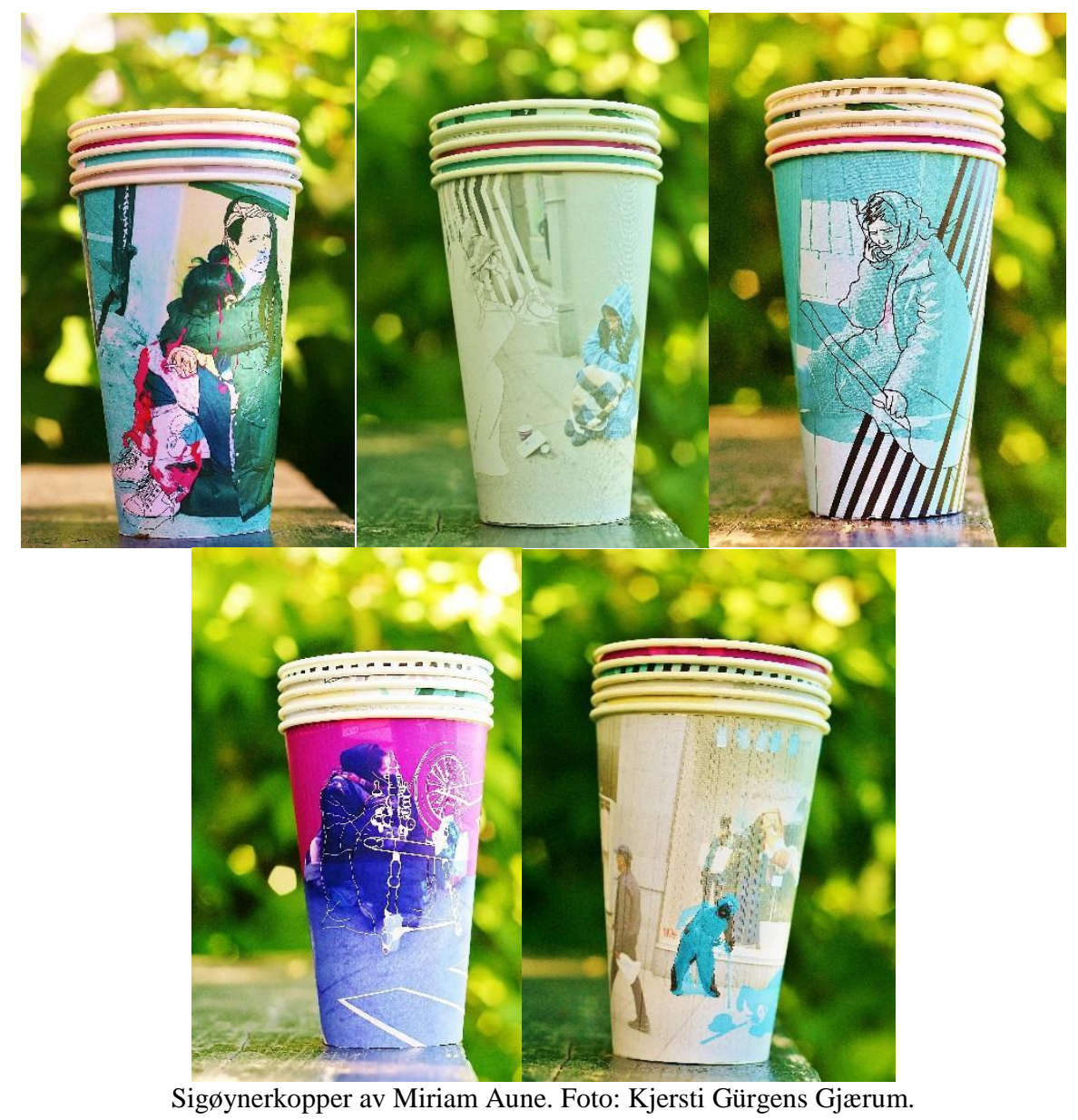

I koppen lå det en lapp med ytringer hentet fra sosiale medier, pressen og fra den da helt ferske Faforapporten When poverty meets affluence: Migrants from Romania on the streets of the Scandinavia, som for eksempel: «Sier $d u$ hei?», «Er romfolk i veien?», «Hva er en fortelling?», «Hva forteller $d u$ om sigøynere?», «Romfolk er kriminelle», «Tiggere burde ut av Norge», «Romfolk eller sigøyner?», «Tør du møte blikket?» og «Går du rett forbi?». Planen var å få hjelp av sigøynere selv til å dele ut koppene, men grunnet mangel på tolk i byen og problemer med å forklare konseptet på engelsk til de omreisende som den sommeren bodde i Harstad, valgte vi å gå bort fra den idéen. En av aktørene delte i stedet ut koppene under forestillingens gang. Blikkene hun møtte fra publikum som brysk ville vifte vekk en tiggende kopp, var interessante å oppleve. Blikkene endret seg da publikum plutselig oppdaget at det var en av aktørene som ga bort en kopp. Det var ikke en kopp som skulle fylles med penger. Koppen var allerede av med refleksjonsspørsmål rettet mot betrakteren. Da så vi forsiktige smil og hender som løftet seg. Andre mumlet «nei, takk» og vendte blikket mot bakken.

Fortellerne selv inviterte lytterne til å ta kontakt etter forestillingen for å snakke med oss om refleksjonslappene i koppene, men det var få som tok kontakt. Lytterne gikk bort noen fortellinger rikere, men de ønsket ikke å bidra i en diskusjon på stedet. Kunne vi ha brukt andre grep for å få til en engasjert debatt, eller var forestillingen i regn og vind lang nok, slik at en ytterligere aktivitet i gågata ikke var realistisk å skape? Vi ser at vi i større kanskje grad burde ha arrangert en debatt ved f.eks. å få noen publikum til å lese opp sin lapp og initiere en samtale der og da, for å se om det kunne skape større publikumsaktivitet. Da måtte vi nok ha presentert færre historier, slik at selve den teatrale hendelsen ikke ble for lang.

\footnotetext{
${ }^{5}$ http://www.fafo.no/index.php/nb/zoo-publikasjoner/fafo-rapporter/item/when-poverty-meets-affluence
} 


\title{
Så med hvilken rett blir din historie min fortelling?
}

Vår erfaring er at man skal være varsom med å fortelle andre kulturers fortellinger, fordi behovet for å forme en god fortelling og formidle den innebærer så mange valg at fortellingen vil kunne komme til å representere noe annet enn det som kanskje var den opprinnelige hensikten. I evalueringen av dette prosjektet ser vi at man nettopp ved å analysere alle valgene fortellerne tar, får en oversikt over hvilke prosesser som foregår når man skaper en fortelling for det offentlige rommet. Dette gir en innblikk i mekanismer som ikke bare fortellere tar i bruk, men som også brukes av formidlere i andre medier. Vi spør oss derfor: Hvis vi som sceniske fortellere ikke formidler disse fortellingene, hvem skal da gjøre det? Hvilke medier kan gi marginaliserte grupper en presentasjonsarena i vår vestlige del av verden?

Vi mener at prosjektet har nådd UNESCOs mål om bevaring av immateriell kulturarv gjennom å anvende teater som medium og benytte en kulturfestival som arena. Vi har villet gi publikum det samme emosjonelle båndet til sigøynere som vi selv opplevede på vår første befaring i Oslos gater. Vi ville få folk til å forstå at sigøynere ikke er en gruppe men enkeltpersoner. I konklusjonen vår ser vi at vi kanskje i større grad burde ha fått med oss sigøynerne som aktører inn i forestillingen. Hadde vi maktet å bryte den vanskelige språk- og kulturbarrieren i møtet mellom romani og norsk, ville vi i større grad hatt forutsetninger for å oppfylle et viktig kriterium i marginalistesforskning: «Noting about us - without us» (Crowther, 2010).

\section{Forfatteromtale}

Mimesis Heidi Dahlsveen har arbeidet som profesjonell fortellerkunstner nasjonalt og internasjonalt siden 1996. Hennes hovedfokus som fortellerkunstner er å samtidsaktualisere tradisjonelle fortellinger. Hun har skapt flere programmer for DKS og en rekke av hennes produksjoner har fătt offentlig støtte. Dahlsveen er førstelektor i muntlig fortellerkunst ved høgskolen i Oslo og Akershus.

Rikke Gürgens Gjærum, professor ved HIOA, med delstilling ved Universitet i Troms $\emptyset$. Dr.at. v/NTNU i 2004, hovedfag i teatervitenskap v/UIO i 1998, allmennlærer og dramapedagog. Arbeider med anvendt teaterforskning, disability art, reminisensteater, estetikkfilosofi og kunstbaserte forskningsmetoder, men også med teaterkritikk, barne- og ungdomsteater og ulike anvendte antistigmatiserende teaterprosjekter $\mathrm{i}$ «Usedvanlig teater».

Thor-André Walløe ble uteksaminert fra Høgskolen i Oslo og Akershus i 2015 med en mastergrad i estetiske fag. Hans masteroppgave har sin faglige forankring i fortellerkunst med fokus på gjenfortelling av andre personers personlige livshistorier. Han arbeider nå som freelance-forteller.

\begin{abstract}
The article explores the stories we choose to tell about others and with what right other people's stories becomes the storyteller's own material. The article discusses the actual collection and interpretation issues when one both is a researcher, facilitator and a storyteller in a project that deals with marginality and vulnerable groups in the community. The ethnographic study article based on the preservation of intangible cultural heritage, generated stories collected from to the gypsies to a storytelling performance "Romfolk-et folk i veien." The purpose of the study was to gather traditional tales, gain insight into representations, expressions and knowledge of who the Gypsies themselves find that they are.
\end{abstract}




\section{Litteraturliste:}

Amdal, E. (2002) Å gjøre gruppeintervju: å skape grupper Trondheim: Senter for teknologi og samfunn, Trondheim: NTNU.

Braid, D. (1996). Personal narrative and experimential meaning. The journal of American folklore, Vol. 109. No. 431, s. 5-30.

Bauman, R. (1997). Verbal art as performance. Illinois: Waveland Press Inc.

Cornog, M., \& Perper, T. (1999). Make love, Not War: The Legacy of Gershon Legman, 1917 - 1999. The The journal of Sex Research, 316-317.

Crowther, N. (2010). Nothing without us or nothing about us? http://disabilitystudies.leeds.ac.uk/files/library/crowther-Nothing-without-us-bt.pdf

Dahlsveen, H. (2008). Innføring i muntlig fortellerkunst. Oslo: Universitetsforlaget.

Dahlsveen, M. H. (2015). Kromosomer - meningsproduksjon, laboratorium og fremmedgjørelse Performativ formidling i ulike medier. In V. Aure, \& K. Bergaust, Estetikk og samfunn: tekster mellom samtidskunst og kunstdidaktikk, Bergen: Fagbokforlaget, 219 - 233.

Dewey, J. (1934) Art as experience, New York: Perigeee Books.,

Djuve, A. Friberg,J. Tyldum, G., Zhang, H. (2015) When poverty meets affluence Migrants from Romania on the streets of the Scandinavian capitals, Oslo: Fafo. http://www.fafo.no/index.php/nb/zoo-publikasjoner/fafo-rapporter/item/when-poverty-meetsaffluence

Gadamer, H.G. (2010) Sannhet og metode, Oslo: Bokklubben.

Haseman, B. C. (2006) A manifesto for performative research. Media International Australia Incorporating Culture and Policy: quarterly journal of media research and resources, s. 98-106.

Hodne, Ø. (1998). Det Norske Folkeeventyret. Oslo: J.W.Cappelens Forlag.

Horsdal, M. (2011). Telling lives. London: Taylor \& Francis.

Hovland, B. I. (2002). Fra fortelling til moralsk handling. Kirke og kultur 1, s. 67 - 98.

https://www.regjeringen.no/no/dokumenter/stprp-nr-73-2005-2006-/id212715/

https://blogg.hioa.no/imkult/

https://www.regjeringen.no/globalassets/upload/kud/kulturvernavdelingen/rapporter_utredninger/imm ateriell_kulturarv_i_norge_ambu_2010.pdf side 100 .

http://educationproject.yale.edu/about/

http://www.avantgarden.no/wp-content/uploads/2012/10/the-construction-of-a-declaration-ofdependence.pdf

http://www.rights.no/2015/09/folkevandringen-moralisme-overstyrer-realiteter/

https://www.regjeringen.no/globalassets/upload/ud/vedlegg/menneskerettigheter/strategi_europa.pdf http://www.utrop.no/Nyheter/Innenriks/23543

http://www.fafo.no/index.php/nb/zoo-publikasjoner/fafo-rapporter/item/when-poverty-meets-affluence Jakobsen, R. (1960). Lingvistikk og poetikk. Heldal, A og Linneberg, A (red.) Strukturalisme i litteraturvitenskapen. Oslo: Gyldendal.

Kiliánovà, G. (2006). Social networks and storytelling communities. Fabula, Vol. 47, s. 241-247.

Kvale. S., Brinkman, S. (2015) Det kvalitative forskningsintervju, Oslo: Gyldendal akademisk.

Legman, G. (1962). Misconceptions in Erotic Folklore. The Journal of American folklore, Vol. 75, No. 297.

Lord, A. B. (2000). The singer of tales. London: Harvard University Press.

Lundby, G. (2003). Historier og terapi Om narrativer, konstruksjonisme og nyskriving av historier. Oslo: Tano Aschehoug.

Lwin, S. M. (2010). Capturing the dynamics of narrative development in an oral storytelling performance: A multimodal perspective. Language and Literature, 357-377.

Magurie, T. (2015). Performing Story on the Contemporary Stage. Palgrave Macmillan.

McLean, K., \& Pasupathi, M. (2011). Old, New, Borrowed, Blue? The Emergence and Retention of Personal Meaning in Autobiographical Storytelling. Journal of Personality, 79:1.

Myerhoff, B. (2010). Stories as equipement for living Last talks and Tales of Barabara Myerhoff. Michigan: The university of Michigan Press. 
Myerhoff, B. (1990). The transformation of consciousness in ritual performances: some thoughts and questions i Schechner, \& W. Appel, By Means of Performance (ss. 245-249). Cambridge: Cambridge University Press.

Okpewo, I. (2003). Oral tradition: Do storytellers lie? Journal of folklore research, 40, 215-232.

Ong, M. (1982) Orality and Literacy: The Technologizing of the world, London: Routledge.

Saldaña, J. (2005). Ethnodrama: An Anthology of Reality Theatre, Walnut Creek, CA: AltaMira Press.

Schechner, R. (1981). Performers and spectators transported and transformed. Kenyon Review, Fall 81, Vol. 3 Issue 4, 83- 83.

Schwartz, S. L. (2004). Rasa performing the divine in India. New York: Colombia University Press.

Solberg, O. (2007). Østenfor sol og vestenfor måne" - eit klassisk eventyr i europeisk og norsk tradisjon. Nordisk tidsskrift for litteraturforskning, Volum 94 (1), s. 3-17.

St.prp. nr. 73 (2005-2006), Om samtykke til ratifikasjon av UNESCOs konvensjon av 17. oktober 2003 om vern av den immaterielle kulturarven.

Thorvaldsen, В. Ø. (2008). Om Trymskvida, tekstlån og tradisjon. Maal og Minne 2, 142-166.

Sturm, B. W. (1999). The enchanted imagination; Storytelling's power to entrance listeners. School Library Media, Vol. 2.

Research Zipes, J. (1993). The trials and tribulations of Little Red Riding Hood: versions of the tale in sociocultural context. South Hadley, MA: Bergin \& Garvey.

Von der Fehr, D. (2008). Når kroppen tenker, Oslo: Universitetsforlaget. 